\title{
Ensuring Quality Assurance In Vocational Education
}

\author{
Ethel E. Idialu, Ambrose Alli University, Nigeria
}

\begin{abstract}
Vocational education emphasises skill acquisition. Quality assurance in vocational education is a concept that is concerned with high performance involving activities with vocational education such as teaching, learning, infrastructures, students' behaviour and the entire academic process. Quality vocational education refers to input and output of the programme, the expressions of standard by which certain goals can be achieved. The concept of quality assurance, its implication for university education cannot be over emphasised as the performance indicators of vocational education still requires serious attention. Good quality education is very necessary in the total development of the student, which ensures proper development, job prospects and the realization of academic goals and objectives. There are varied factors working against the realisation of quality vocational education in our universities today. The focus of this paper therefore is to highlight the concept of quality assurance in vocational education, factors militating against it, and strategies for ensuring quality assurance were recommended. The paper concludes that if the quality assurance in vocational education must be achieved in the universities there is the need for urgent steps to be taken towards reformation of the programme.
\end{abstract}

Keywords: Performance; Motivation; Funding; Remuneration; Assessment; Accreditation

\section{INTRODUCTION/CONCEPT OF QUALITY ASSURANCE}

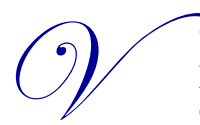

ocational education can be described as an aspect of education that is concerned with the training and preparation of persons for qualified skilled performance on any task laid before him/her. It is a type of educational training or retraining that is focused on making the learner or students more productive through performance in paid employment or self employment. It is the central point on which a country's socioeconomic, technological, cultural advancement must be built. This type of education involves the application of specialized learning techniques in the realization of both educational and societal objectives, the main objectives revolve around the socio-economic, industrial and technological objective that will be evident in improved standard of living for citizens as well as in economic stability, industrial harmony and technological advancement. Vocational education therefore equips an individual for economic independence, self - actualization and also being productive in various fields of learning. This can lead to societal development and socio-economic security. It also has the economic role of providing qualified manpower by enabling individuals to make use of complex technology, the emphasis is not only on provision of skilled labour for a dynamic one, especially one with changing societal needs for technological advancement (Ulinfun, 1986).

Idialu (2007) stressed that in order to ensure high quality in the teaching, examination and improved learning in vocational and technical education, it is essential that the student have opportunities to learn from teachers whom they meet, and continue to demonstrate throughout their career, rigorous professional standards. The achievement of quality standard in vocational education is an on-going process that is concerned with pre-and post service education, monitoring, professional development and certification the main goal of vocational education is to create and improve opportunities for high quality learning which is measured through output/performance The relevance of vocational education in Nigeria has been emphasised to ensure high quality in vocational education the new national policy on education in Nigeria (1981) states the functions as:

- $\quad$ To provide manpower in applied science, technology and commerce particularly at sub-professional levels 
- $\quad$ To provide the technical knowledge and vocational skills necessary for agriculture, industrial, commercial and economic development

- $\quad$ To provide people who can apply scientific knowledge to the improvement and solution of environmental problems for the convenience of man

- $\quad$ To give an introduction to professional studies in engineering and other technologies

- $\quad$ To give training and impart the necessary skills leading to the production of craft men, technicians and other skilled personnel who will be enterprising and self reliant, and to enable young men and women to have an intelligent understanding of the increasing complexity of technology

Vocational education cannot function properly unless there is high quality in the standard of teaching, materials available, teaching methods and proper evaluation of students in the programme. The assessment of quality teaching is an on-going, multi-dimensional process which should be based on process and product.

Events have shown that countries and individuals are not able to harness human and non-human resources efficiently towards the realisation of specific socio-economic and technological goals which brings us to the fact that there is need for ensuring quality vocational education programme. Successful implementation of any education programme and the effectiveness in achievement of set goals depend very much on adequate materials and resources available. The input on individuals and institutions of learning, can determine to a large extent the realisation of the philosophy of vocational education.

Quality can be described as standards of something as compared to other things that is the degree of excellence. High quality teaching/instruction can be regarded as the goodness or effectiveness in teaching/instruction which can result in student learning and satisfaction. Quality teaching and learning in vocational education therefore ensures that students acquire the knowledge, skills and competences that are appropriate for their area of responsibility. There is the need to have teaching standards and develop challenging examinations to document and recognize accomplished teaching. Quality assurance is an essential tool required to ensure efficient vocational educational programmes in our schools for the achievement of manpower development and skill acquisition in our societies.

Quality assurance therefore can be described as ways of managing the educational sector, the service provided to ensure that they are kept at high standard that will positively affect its products. Crosby (1979) highlighted the fact that to realize zero defects in the work process is a difficult one but maintained that it can be achieved through the use of a quality assurance system that is laid down procedures on how work should be done to achieve a specified standard. It involves injecting quality into the process of training from the very beginning to ensure that the products meet a specified standard. For vocational education to attain quality, it requires working with already established procedures and standards as established by regulatory agencies in the different countries. For example, in Nigeria we have the National Universities Commission (NUC), National Board for Technical education (NBTE), National Commission for Colleges of Education (NCCE) and so many others. These are agents of ensuring quality in vocational education. The duty of ensuring quality actually rests on the teachers/lecturers who are directly in charge of implementing the educational programmes. Quality assurance in vocational education must be viewed holistically from requirements of entry into the programme, duration, quality and number of teacher/lecturers, facilities, instructional materials available, school environment/accommodation, examinations, results, certificate, grading system, exam question items, supervision, moderation etc. It has to be a total package to ensure a meaningful product. The concept of quality assurance hinges on education monitoring. Which is a complete concept aimed at systematically linking planning, analysis and control. Quality assurance must, therefore, involve internal and external influence to ensure efficiency and benefit desired.

\section{PARAMETERS FOR QUALITY ASSURANCE IN VOCATIONAL EDUCATION}

These are things that can be used to decide the way in which teaching and learning activities can be done. They can also be used to judge the extent to which set objectives have been achieved in this regards. Some important parameters that will help to achieve great success are as follows: 


\section{Quality of Teachers/Trainers}

The quality of teachers/trainers has very serious impact on the assessment of quality in our universities. The teacher/trainers need to be adequately qualified for the job of impacting knowledge, they must be equipped with the principles and practice of vocational education, and this parameter focuses on their qualification, experiences, competencies, capacities and acquisition of desirable skills to carry out certain task.

\section{Instruction}

The quality of instruction must be backed up with good teaching methods, adequate facilities to aid teaching and learning, equal learning opportunities for all students, provision of a conducive learning environment and communal assistance to students and teachers. Adegoke (2007) emphasised that no meaningful development can take place without adequate man power, trained competent teachers who are product of good teacher education. Theoretical and practical vocational teacher education requires a proper grooming in vocational skill acquisition, sciences and specialized knowledge. The curriculum of vocational educational programme must meet the set standard required to improve the standard of living.

\section{Accreditation of Programme}

Accreditation of programmes is desirable for ensuring quality assurance. In Nigeria, various institutions and regulatory bodies set up minimum standards to guide the operators of the systems. These include the accreditation of courses and qualification/certification offered to students at the end of the programme. This issue cannot be overlooked in quality assurance system the regulatory body established to ensure minimum standard in the university in Nigeria, NUC, looks at accreditation model, awarding body, accreditation status, industry/social partner development for instance, Amadike (2007) reported that the document for the minimum academic standard by consultative forum provided specification for floor space and holdings, staff /students ratio, for effective teaching and learning, the curriculum and entry/graduation requirement for each discipline amongst others. The minimum academic standard for universities became the basis for accreditation off all degrees and programmes for all universities in Nigeria.

\section{Inspection/Monitoring}

All nations around the globe include some type of auditing at one time or the other in their vocational education programme as part of the on-going process of ensuring quality in the system. In most cases delegated agencies are assigned to carry out this task. Monitory puts the management team of institutions to strive to meet set standards.

\section{Evaluation}

These include learner user surveys, internal and external appraisals, validation, moderation procedure, input process - output for accessing quality, etc.

\section{FACTORS MILITATING AGAINST QUALITY ASSURANCE IN VOCATIONAL EDUCATION}

Vocational education programmes are designed for people who can profit and progress by it. In order to accomplish these outcomes, quality must be the keyword. The programme today is bedevilled with numerous problems some of which are highlighted as follows:

\section{Inadequate Funding of Vocational Education}

Inadequate funding is a very serious issue affecting vocational education programme. Amadi (2007) remarked that in-spite of the efforts of the different governments of the federation to provide funds for higher education, and the huge amount of money expended, higher education still lacks fund to implement various programmes. Inadequate financial resources in the higher institutions have the effect of limiting the educational 
development policy of both state and local governments. Basic infrastructures are lacking in our universities workshops are not provided for the program in some school. Even where they are available, they are either empty or stocked with obsolete items. The strict implementation of vocational education will remain elusive without competent vocational teachers. Many institutions producing vocational teachers are not able to do so due to low level of funding which then results in lack of equipments, accommodation, workshop, training materials and money for maintaining equipments. Ebenebe (1991) advised government to increase funding of these programmes stating that for institutions to perform their educational and training assignments properly and thus produce the right calibre of people that can win the respect of industry and the public, they need to be adequately equipped. Vocational education is practical oriented and the absence of infrastructures, equipments and materials due to poor funding is bound to affect the competence of the products and the subsequent implementation of the programme.

\section{Staff Quality and Quantity}

The quality of lecturers/teachers employed in universities and other agencies responsible for the training of vocational education teachers is very crucial. Adegoke (2002) identified the quality of a teacher in charge of training as one of the indicators of standards in teacher's education. The continuous shortage of vocational experts is a major factor affecting the development and quality of vocational education in Nigeria and other parts of the world. As a result of inadequate qualified personnel most of the equipment and machines in some schools are easily abandoned because they lack competent hands to manipulate them. The need for technical manpower in the present stage of development is very important as one strive towards being a self reliant nation it is noted that no meaningful development can take place without a conscious effort to develop manpower in vocational areas. Quality cannot be guaranteed when the quality and quantity of personnel are inadequate to meet the desired expectation.

\section{Lack of Facilities}

The connection between existing facilities the course curriculum and minimum standard is very important and a vital point to consider for quality assurance to be maintained, many institutions running vocational education programmes struggle to have sufficient facilities, thus it is difficult for them to procure necessary equipments for the programme and this results to over utilization of the existing facilities it is important to note that no curriculum can be adequately covered without adequate facilities to work the curriculum out and no talk of standard can be achieved when the curriculum is not adequately covered. Salisu (2000) in her study of the influence of school physical resources on students' academic performance, conclude that there is significant difference in the academic performance of students in schools with adequate facilities and those with adequate facilities.

\section{Retraining the Trainers}

The socio economic and societal needs today are enormous and varied. New machines and tools are required daily to meet the complex industrial needs of modern times in the area of vocational education. Looking at today's situation the vocational skills being exhibited by teachers/lecturers may not meet the demands of tomorrow for technical progress. Moreover, current skills and bodies of knowledge create a need for retraining of teachers/lecturers. On the job training is very necessary for the success of today's vocational teacher and also a tool for ensuring quality assurance in vocational education.

\section{Poor Societal Attitude}

This is concerned with the poor image of vocational education as perceived by the Nigerian public; people still prefer to go about looking for white jobs as a result of low status associated with vocational education (Gambo, 1980). Some parents want their children to be medical doctors, accountants, lawyers, administrators and politicians because of the negative attitude toward vocational education accounts for the decline and lack of interest by the students in the teaching of education in schools. The teacher then has an uphill task teaching people who are not interested in the subject that is being taught. 


\section{Poor Remuneration of Vocational Teachers}

This is a serious problem affecting quality in our educational system in most states in Nigeria and other parts of Africa. Salaries, allowance, and entitlements are sometimes paid in arrears or at times they are being denied. This factor has led to brain drain in recent times as professors and some University dons proceed to other countries in hundreds to search for better conditions of service without replacement. Amadike (2007) stressed that poor remuneration is responsible for the poor attitude to work of staff; they go about doing their own business instead of concentrating on how to improve the quality of teaching and learning vocational education in the school. This accounts for ineffectiveness and affect quality assurance.

\section{Poor Administration and Regular Supervision of Vocational Education Programme}

Poor administration and supervision of vocational education programme can greatly affect the quality assurance in schools, lack of co-ordination between the various federal and state agencies responsible for the administration of vocational education program has resulted in costly duplication of efforts and inability to design appropriate curricular for the Nigerian youth (Osuala, 1981). Government, administrators, and proprietors do not take internal and external supervision seriously in the institutions.

\section{Examination Malpractice}

Examination almost at all levels is bedevilled by malpractice. This is because students are not ready to work hard, read or go through the normal academic exercise; rather they prefer short cuts and the easy way out. Hence they are often lured to employing malpractices of various kinds during examination and if this is not stopped quality cannot be achieved.

\section{Poor Assessment Methods}

The course content of vocational education in schools still consists of the cognitive aspect of learning instead of productive indicators. The assessment ought to be both practical and theoretical which will enable them function properly in the society; assessment should be an ongoing exercise.

\section{Absenteeism of Teachers and Students}

Lecturers leave their duties for other personal assignment without teaching and covering the syllabus and at the end set examination questions that cover the syllabus that they did not teach leaving the students to their own faith. On the part of the students, some of them also neglect their lectures and only appear during examination. Consequently, this set of students cannot write anything meaningful in the examinations.

\section{Total Disregard of Accreditation Report}

In some institutions full accreditation reports are always disregarded or complied with. It has been observed that some programmes after being denied accreditation still go on to run the programmes without addressing the deficiencies observed during accreditation which undermines quality assurance in the institution.

\section{POSSIBLE WAYS OF ENSURING QUALITY ASSURANCE IN VOCATIONAL EDUCATION}

To ensure quality assurance in vocational education there is need to identify possible strategies that could bring about quality in teaching and learning of vocational education. Some of these strategies include:

\section{Skill Acquisition and Competency}

Emphasis should be on skill acquisition by vocational education teachers. Competency should be judged by both performance at examinations and acquisition of usable and valuable skills, lectures must be well equipped with knowledge, skills, competences required for impacting knowledge in the teaching and examination of vocational education subject in schools. 


\section{Adequate Funding}

Inadequate funding is a major problem of vocational education in many developing countries such as Nigeria. Vocational education is a money consuming venture since this is the only sure way of bringing development into any nation, it should be properly funded to bring about the realisation and achievement of its aim and objectives. The needs of vocational education which include purchase of equipments and materials for teaching, maintenance of equipment, payment of allowances, are quite enormous and need to be addressed promptly. The government should provide funds for the vocational education to have a meaning in the real sense. Quality can be achieved only in an atmosphere of financial sufficiency which will help in the provision of infrastructure, laboratories, chemicals, classrooms etc.

\section{Accreditation}

The system of accreditation of academic programmes in vocational education in higher institutions is an important tool for maintaining academic standards and excellence because of its valued importance, and it should be done regularly to maintain and ensure quality assurance in vocational education. In Nigeria, infrastructural facilities and curriculum contents are the two broad areas identified for meaningful standards in schools. Maryland higher education commission (2006) viewed accreditation as a process of self regulation and peer review adopted by the educational community. It emphasised that accreditation ensures a basic level of quality in education. The quality of education will improve; if lecturers and other staff are properly monitored and supervised they will be dedicated and efficient in their duties. This will further strengthen the quality of teaching and learning in schools. Authorities of institutions must adhere to findings and recommendations of accreditation teams.

\section{Adequate Staffing/Staff Development}

There should be provision of adequate teaching manpower in vocational institutions. Manpower should be competent, diligent and qualified teaching and non teaching staff. The National Universities Commission (NUC) stipulates that the minimum qualification for lecturing in the university is a master degree. Non professional teachers should not be allowed to teach vocational courses. Odor (1995) viewed staff development as the process of training and retraining of staff members in an organisation for the purpose of acquiring more academic or professional knowledge, skills and competencies for increased efficiency in their primary functions for professional growth and development. It is very important that institutions prescribe a suitable programme for training and retraining of its staff. This will ensure maximum contribution to developments and the progress of vocational programmes in the institutions.

\section{Provision of Adequate Facilities}

To teach courses in vocational education effectively there must be adequate provision of facilities in terms of space, equipments, infrastructures, and physical facilities. The lecture halls must have instructional materials and be conducive for learning. The training environment should be like the work environment, teaching with real materials and real situation can help to encourage the students to learn and can greatly enhance quality. Lack of facilities to poor service conditions can lead to self dissatisfaction and stress making them less efficient and lack commitment to work.

\section{Enhancement of Societal Attitude towards Vocational Education}

Positive attitude towards any subject contribute to ensuring quality assurance. Gambo (1980) indicated that there is still a strong tendency towards white collar jobs as a result of low status associated with most kind of vocational education. In the light of the importance of vocational education and to enhance societal attitude government should endeavour to raise the vocational teacher's socio-economic status, there should be increased public awareness of the value and benefits of vocational education and what role it is expected to play in the nation's technological development. 


\section{Motivations/Remunerations of Teachers/Lecturers}

Vocational education lecturers should be motivated to enjoy their jobs rather than painfully enduring it. For instance, they should be encouraged in the prompt payment of salaries, allowances and other entitlements like promotion, in-service training, conference attendance and other relevant conditions of service should be given to them as and when due. Optimum performance on the job could only be guaranteed when they are well motivated and this will ensure quality teaching in schools.

\section{CONCLUSION/RECOMMENDATIONS}

From the foregoing, the need for quality assurance in vocational education cannot be over emphasised as the performance indicators of the programme still leave so much to be attended to in answering the numerous questions of quality of output, marketability, entrepreneurship, and the technological and educational policies. Since education is paramount in national development, all stakeholders and institutions should put up concerted effort in ensuring quality in education. Considering the value of quality vocational education, the following recommendations have been proffered to ensure quality assurance in vocational education:

- $\quad$ The government should make it a point of duty to fund and provide the necessary facilities and equipments for vocational education.

- The government who is a major stakeholder in the education sector should appreciate the strategic position of vocational education and increase its budgetary allocation to the sector.

- National Universities Commission should be given the authority to penalise universities that flaunt accreditation report and continue with denied programmes and other regulations on quality assurance.

- $\quad$ Teachers/lecturers should endeavour to prepare adequately for their lessons by employing the use of real or concrete materials as instructional materials.

- $\quad$ There should be regular employment of qualified lecturers in the universities to avoid shortage of staff in the departments of vocational education.

- Universities should be directed to set up quality assurance units to supervise and monitor academic programmes and activities on campuses.

- $\quad$ Experts in vocational education should teach vocational education courses and headship of vocational education department should be strictly restricted to vocational education professionals.

- $\quad$ The welfare of vocational teachers should be promptly attended to by stakeholders. For example, regular payment of salaries, allowances, promotions and remuneration.

- $\quad$ There should be provision for in-service training and retraining of teachers/lecturers to equip them with new ideas, methods of the value and benefit of vocational education and what role it is expected to play in the nation's technological development.

\section{AUTHOR INFORMATION}

Dr Ethel Idialu is an associate professor in the Department of Vocational and Technical Education (Home Economics unit), Faculty of Education, Ambrose Alli University, Ekpoma. She holds a bachelors degree in Home Economics Education, M. Ed degree in guidance and counselling, M. Ed degree in Vocational Teacher Education (Home Economics) and a Ph.D. in Gender and Population Education. She has utilized her wealth of experience and knowledge as a home economist, researcher and lecturer in the university. She has attended and presented papers in conferences, workshops, seminars, symposia and other academic activities. She has written articles in academic journals, and being invited as guest lecturer at academic and social gatherings. She is married with children. Contact: Dr (Mrs) Ethel E. Idialu, Department Of Vocational And Technical Education, Ambrose Alli University Ekpoma, Nigeria. E-mail: Ethelidialu@yahoo.com

\section{REFERENCES}

1. Adegoke, K.A. (2002.). Standard in teacher preparation in Nigeria: some highlights. Journal of Education for National development (JOEND), Vol. 4 No. 1 and 2. Unique Educational Publishers 1-6. 
2. Akamobi, I (2005). Strategies for Ensuring Quality in the Teaching of Vocational Education in Secondary Schools in Journal of Qualitative Education Vol. 1 No 2.

3. Amadi, M. N. (2007). Funding initiative in higher education. National Association of Educational Administration and Planning (N.A.E.A.P) Publication PP 544_554.

4. $\quad$ Amadike, N.N.F. (2007). Quality Control and Assessment in Tertiary Institution. National Association of Educational Administration and Planning (N.A.E.A.P) Publication PP 423-430.

5. Babalola J.B. (1997). Cost and financing of university Education in Nigeria. Higher Education Journal 36, pp 43-66.

6. Babalola J.B., Akpa, G.O., Ayeni, A. O and Adedeji, S.O.(2007). Access, Equity and Quality in Higher Education. National Association of Educational Administration and Planning (N.A.E.A.P) Publication.

7. $\quad$ Crosby P.B (1979). Quality is Free. New York, McGraw-Hill.

8. Federal Government of Nigeria revised (Revised 1981) National policy on education, Lagos Federal Ministry of Information.

9. Gambo, A.S (1980). Technical Education for rapid development: Nigeria journal of technical education Vol. 1 and 2, Pp 32-34.

10. Idialu (2007). Quality Assurance in the Teaching and Examination of Vocational and Technical Education in Nigeria. U.S.A. College Student Journal Vol. 41, No. 3.

11. Maryland Higher Education Commission (2006). Higher Education in Maryland Annapolis Bestgate Road.

12. National University Commission (2002). Quality Assurance in Nigeria Universities Vol. 1, Rankings of Nigeria universities according to performance of their academic programs in 1999 and 2000 accreditation exercise Abuja: NUC.

13. Odekunle, K.S. (2001). Finding of University Education Democratic Rule in Nigeria: Problems and Prospects. Proceedings of the $12^{\text {th }}$ General Assembly of S.S.A.N.

14. Odor, G. O. (1995). Administration of schools in Nigeria: Theory and practice. Benin City: Monose Amalgamates.

15. Salisu, R. A. (2001). The influence of school of physical resources on student academic performance Unpublished M.Ed dissertation Department of Educational Administration, University of Lagos.

16. The international comparative higher education finance and accessibility, Project http/www.gse.buffalo/edu/org/inthighered finance/region africa-Nigeria html retrieved 9/19/2006

17. Unlinfun F.E (1986) Business Education utility education in a developing economy, Business Education Journal Vol. 1, April. 